\title{
SISTEM PENCATATAN REKAM MEDIS DIGITAL KLINIK MITRA MEDISTRA BERBASIS WEB DENGAN LARAVEL DAN MYSQL
}

\author{
(Web Based Medical Record Logging System for Clinic Mitra Medistra Using \\ Laravel and MySQL)
}

\author{
Hanifah Binti Nu'man ${ }^{[1]}$, Wirarama Wedashwara ${ }^{[1]}$, I Gusti Lanang Eka Tanaya ${ }^{[2]}$ \\ ${ }^{[1]}$ Dept Informatics Engineering, Mataram University \\ J1. Majapahit 62, Mataram, Lombok NTB, INDONESIA \\ ${ }^{[2]}$ Klinik Mitra Medistra, Mataram, Indonesia \\ Email: hnfhbn@gmail.com,wirarama@unram.ac.id
}

\begin{abstract}
Abstrak
Klinik Mitra Medistra merupakan klinik swasta yang sedang berkembang di Mataram, Lombok. Sistem pencatatan rekam medis di klinik Mitra Medistra sejauh ini masih secara konvensional yaitu berupa pencatatan manual di buku. Pengabdian masyarakat yang dilakukan ini bertujuan mengembangkan sistem untuk melakukan pencatatan rekam medis dalam bentuk digital menggunakan website dengan framework Laravel dan basis data MySQL di Klinik Mitra Medistra. Sistem ini ditujukan untuk memudahkan pencatatan rekam medis serta mengurangi resiko kerusakan data. Hasil pengujian Black Box menunjukkan fungsional sistem dapat berjalan dengan baik sesuai yang diharapkan.
\end{abstract}

Keywords: Rekam medis, Laravel, MySQL, Black box.

\section{Pendahuluan}

Klinik Mitra Medistra merupakan sebuah klinik swasta yang belum lama berkembang di Mataram, Lombok. Meskipun begitu, pengunjung yang berobat di klinik ini terus bertambah setiap harinya. Bagi beberapa pasien pun klinik ini sudah menjadi tempat berobat andalan mereka. Klinik Mitra Medistra terus berkembang dan sedang berencana untuk lebih melakukan upgrade menjadi institusi kesehatan yang lebih besar.

Seiring berkembangnya klinik Mitra Medistra, dengan pasien yang terus bertambah, maka sudah jelas jumlah data yang dicatat oleh klinik menjadi semakin banyak. Data ini salah satunya berupa rekam medis. Menurut PERMENKES No.269/MENKES/PER/III/2008 Tentang Rekam Medis dalam Pasal 1 ayat (1): "Rekam Medis adalah berkas yang berisi catatan dan dokumen tentang identitas pasien, pemeriksaan, pengobatan, tindakan dan pelayanan lain yang telah diberikan kepada pasien". Dan dalam UU No.29 Tahun 2004 Tentang Praktek Kedokteran Pasal 46 ayat (1) "Setiap dokter atau dokter gigi dalam menjalankan praktik kedokteran wajib membuat rekam medis", ayat (2)" Rekam medis sebagaimana dimaksud pada ayat (1) harus segera dilengkapi setelah pasien selesai menerima pelayanan kesehatan, ayat (3)" Setiap catatan rekam medis harus dibubuhi nama, waktu, dan tanda tangan petugas yang memberikan pelayanan atau tindakan". Sedangkan dalam Penjelasan Pasal 46 ayat (1) berbunyi:" Rekam Medis adalah berkas yang berisi catatan dan dokumen tentang identitas pasien, pemeriksaan, pengobatan, tindakan,dan pelayanan lain yang telah diberikan kepada pasien".

Sistem pencatatan di klinik Mitra Medistra sejauh ini masih secara konvensional yaitu berupa pencatatan manual. Dokter yang bertugas akan menuliskan hasil pemeriksaan pada kertas kontrol, kemudian data tersebut direkap dengan dituliskan kembali pada buku besar khusus rekam medis. Sistem pencatatan manual ini memiliki banyak kekurangan, yaitu sulitnya melakukan analisa atau pencarian pada data, resiko hilangnya data jika buku rusak atau hilang, serta tidak teraturnya data seperti nomor rekam medis.

Oleh karena itu, sebagai sebuah solusi yang dapat meminimalisir kerusakan data dan mempermudah pengolahan data, dibutuhkan suatu sistem informasi untuk menyimpan data secara digital. Sistem ini juga akan mempermudah kegiatan pencatatan oleh dokter maupun perawat. 
Tujuan dari pembuatan Sistem Pencatatan Rekam Medis Klinik Mitra Medistra ini adalah merancang sebuah sistem pendataan untuk mendigitalisasi pencatatan data rekam medis pasien Klinik Mitra Medistra. Manfaat dari Sistem Pencatatan Rekam Medis Klinik Mitra Medistra adalah sebagai berikut.

a. Membantu dokter dan perawat untuk melakukan pencatatan hasil pemeriksaan pasien dengan lebih efisien.

b. Mengorganisir data sehingga lebih tertata rapi dan mudah dilakukan pencarian.

c. Mempermudah jika nantinya data rekam medis ingin digunakan untuk kegiatan penelitian tertentu.

d. Meminimalisir kerusakan data rekam medis pasien di klinik Mitra Medistra.

\section{Tinjauan Pustaka}

\subsection{Sistem Informasi}

Sistem adalah kumpulan orang yang saling bekerja sama dengan ketentuan-ketentuan aturan yang sistematis dan terstruktur untuk membentuk satu kesatuan yang melaksanakan suatu fungsi untuk mencapai tujuan. Sedangkan informasi adalah data yang diolah menjadi lebih berguna dan berarti bagi penerimanya, serta untuk mengurangi ketidakpastian dalam proses pengambilan keputusan mengenai suatu keadaan. Sehingga, sistem informasi merupakan suatu kombinasi teratur dari orang-orang, hardware, software, jaringan komunikasi, dan sumber daya data yang mengumpulkan , mengubah, dan menyebarkan informasi dalam sebuah organisasi [1].

\subsection{Basis Data}

Basis data dapat didefinisikan sebagai himpunan kelompok data yang saling berhubungan yang diorganisasi sedemikian rupa agar dapat dimanfaatkan kembali dengan cepat dan mudah. Basis data dapat disimpan dalam beberapa model, salah satunya model basis data relasional. Basis data dalam model relasional disusun dalam bentuk sejumlah tabel untuk menggambarkan data serta hubungan antara data-data tersebut. Salah satu pemodelan data konseptual yang paling sering digunakan dalam proses pengembangan basis data bertipe relasional adalah Entity Relationship Diagram (ERD) [2].

\subsection{Diagram UML}

Unified Modelling Language (UML) adalah "bahasa" standar untuk mendeskripsikan, memvisualisasikan, dan mendokumentasikan sistem yang berorientasi objek. Beberapa jenis UML yang menggambarkan ciri-ciri behavior/metode/fungsi dari sebuah sistem atau business process adalah use case diagram dan activity diagram.

\subsubsection{Use case diagram}

Use case diagram adalah diagram yang menggambarkan aktor, use case, dan relasinya sebagai suatu urutan tindakan yang memberikan nilai terukur untuk aktor.

\subsubsection{Activity diagram}

Activity diagram adalah diagram UML yang menggambarkan aktivitas-aktivitas, objek, state, transisi state, dan event. Dengan kata lain menggambarkan perilaku sistem untuk aktivitas tertentu [4].

\subsection{MySQL}

MySQL merupakan sebuah layanan database management system yang bersifat open source, multiuser, dan multithread. MySQL dapat menyimpan data relasional dengan menggunakan bahasa SQL.

\subsection{PHP}

Hypertext Preprocessor (PHP) adalah salah satu bahasa pemrograman skrip yang dirancang untuk membangun aplikasi web. Ketika dipanggil dari web browser, program yang ditulis dengan PHP akan di-parsing di dalam web server oleh interpreter PHP dan diterjemahkan ke dalam dokumen HTML, yang selanjutnya akan ditampilkan kembali ke web browser. Kerena pemrosesan program PHP dilakukan di lingkungan web server, PHP dikatakan sebagai bahasa sisi server (server-side). Oleh sebab itu, seperti yang telah dikemukakan sebelumnya, kode PHP tidak akan terlihat pada saat user memilih perintah "View Source" pada web browser yang digunakan [3].

\subsection{Laravel}

Laravel adalah sebuah framework aplikasi website berbasis PHP yang dirancang untuk mempermudah pengkodean dalam mengembangkan sistem.

\subsection{Pengujian Black Box}

Black Box testing merupakan pengujian perangkat lunak yang didasarkan pada detail aplikasi seperti tampilan aplikasi, fungsi-fungsi yang ada pada aplikasi, dan kesesuaian alur fungsi dengan bisnis proses yang diinginkan oleh pengguna. Pengujian Black Box tidak melihat dan menguji kode program. Kegiatan penguji/tester pada Black Box 
Testing adalah membuat tesst case untuk menguji fungsi-fungsi yang ada pada aplikasi, membuat test case untuk menguji kesesuaian alur kerja suatu fungsi di aplikasi dengan requirement/spesifikasi yang dibutuhkan pengguna, serta mencari bugs/error dari tampilan (interface) aplikasi [5].

\section{Metode Pengabdian masyarakat}

\subsection{Metode Perancangan Sistem}

Dalam melakukan pengabdian masyarakat ini yaitu menyelesaikan Sistem Informasi Pencatatan Rekam Medis Klinik Mitra Medistra, menggunakan metode Waterfall dalam pengembangannya.

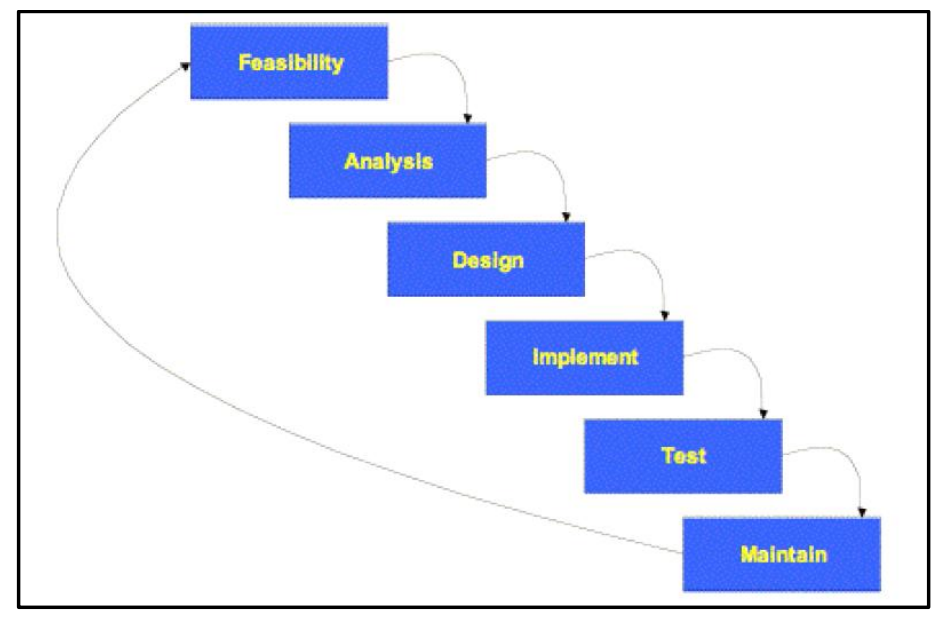

Gambar 1. Metode Waterfall

Tahap pertama adalah feasibility study, yaitu tahap menguji kelayakan Sistem Pencatatan Rekam Medis Klinik Mitra Medistra, apakah sistem ini benar sesuai untuk permasalahan di lapangan yaitu untuk pencatatan rekam medis yang ada atau tidak.

Kemudian tahap kedua adalah system analysis, yaitu tahap analisis kebutuhan sistem, baik kebutuhan fungsional (hal-hal yang harus dilakukan sistem), maupun kebutuhan nonfungsional (yaitu hal-hal yang harus dimiliki sistem). Tahap ketiga adalah tahap design, yaitu tahap desain sistem, meliputi data apa saja yang dibutuhkan dalam menyimpan data pasien dan rekam medisnya, fitur apa saja yang diinginkan, siapa saja calon pengguna sistem, dan seperti apa tampilan sistem.

Tahap berikutnya adalah implementation, dimana pada ini dilakukan implementasi hasil analisis sistem dan design sistem ke dalam bentuk sistem informasi berbasis website.Pada tahap ini dilakukan proses pengkodean aplikasi menggunakan Bahasa pemrograman berbasis web dengan framework Laravel (PHP). Tahap ini dipastikan selesai jika semua fitur yang diinginkan user dan telah didesign di tahap sebelumnya telah berhasil dibuat seluruhnya menjadi sebuah sistem atau aplikasi web.

Kemudian tahap selanjutnya menuju testing, yaitu tahap menguji hasil implementasi sistem. Dan yang erakhir adalah tahap maintenance, yaitu sistem akan dipelihara dengan pengecekan dan perbaikan secara berkala.

\subsection{Desain Sistem}

\subsubsection{Entity relationship diagram}

Dapat dilihat dari ERD pada Gambar 7 bahwa data yang dibutuhkan untuk membangun Sistem Pencatatan Rekam Medis Klinik Mitra Medistra ini ialah data admin sebagai pengelola user, data dokter dan perawat sebagai user, kemudian juga dibutuhkan untuk diolah yaitu data pasien serta antrian dari pasien, dan data rekam medis itu sendiri. 


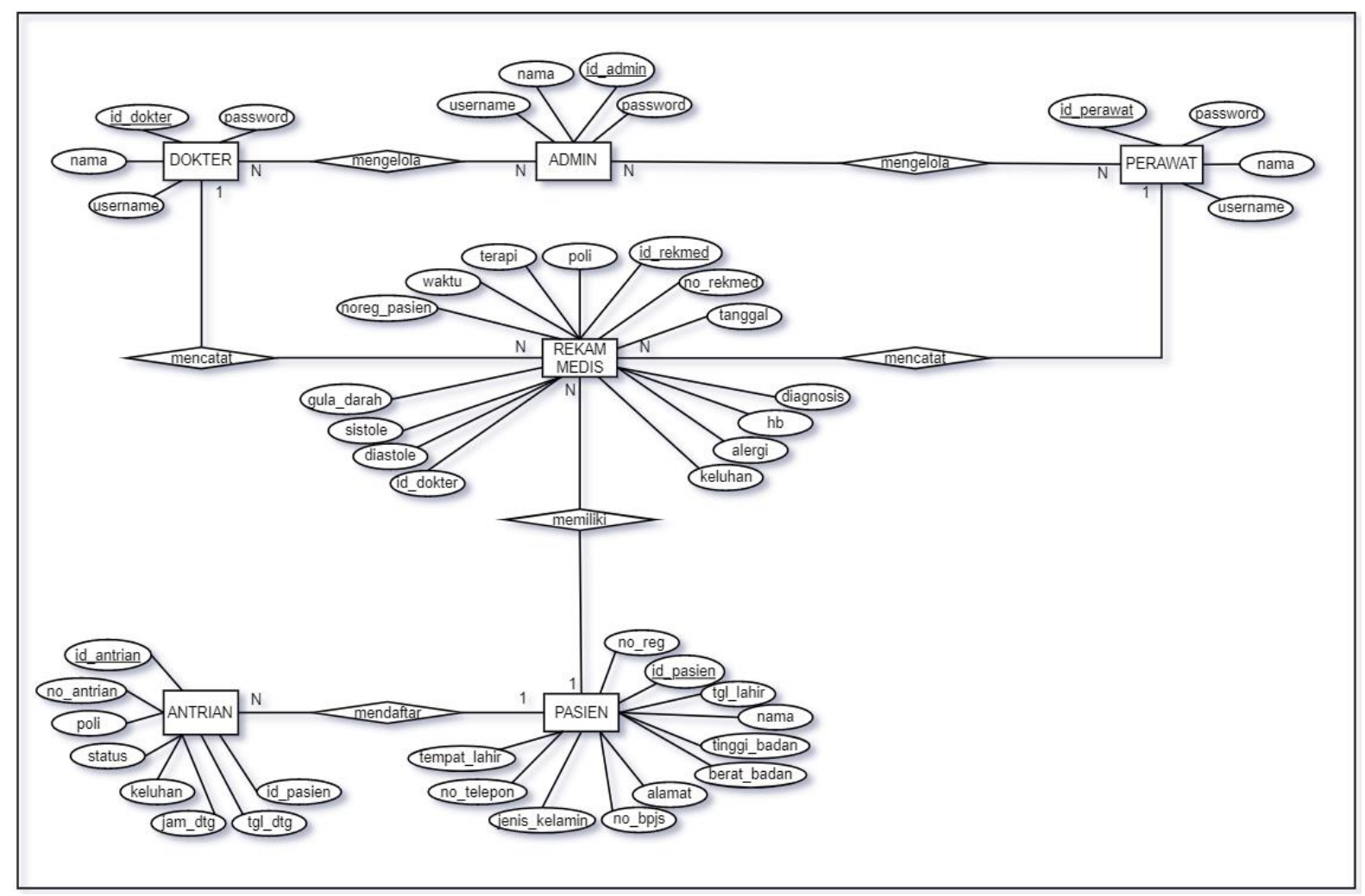

\subsubsection{Activity diagram}

Gambar 7. Entity Relationship Diagram

a. Proses login

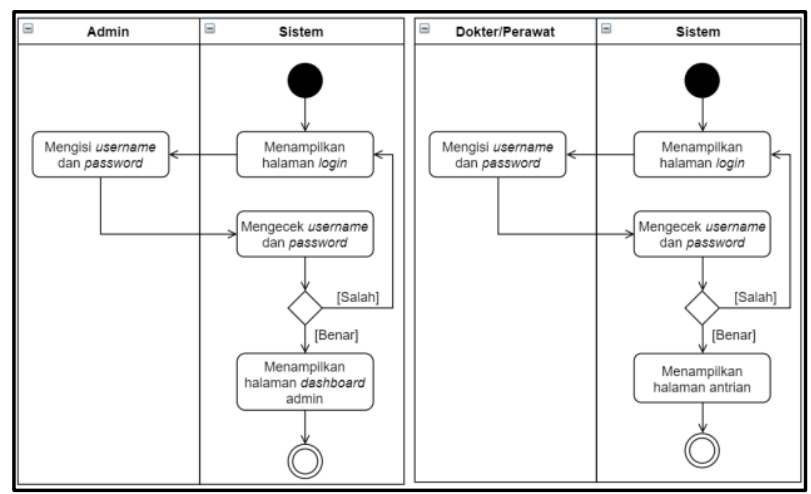

Gambar 8. Proses Login

Untuk melakukan login, admin perlu mengisikan username dan password pada halaman utama yang pertama kali akan menampilkan form login. Kemudian sistem akan menjalankan pengecekan apakah username dan password tersebut ada di database dan cocok satu sama lain. Jika benar, maka sistem akan menampilkan halaman dashboard admin yang mana default-nya adalah halaman data dokter. Jika salah, sistem akan kembali ke halaman utama dengan menampilkan alert 'username atau password yang anda masukkan salah'.

Sedangkan untuk Proses login bagi dokter dan perawat sama-sama melibatkan pengisian dan pengecekan username dan password seperti user lainnya diatas, dan jika data benar maka sistem akan menampilkan halaman antrian pasien.

\section{b. Proses mengelola data user}

Dalam Sistem Pencatatan Rekam Medis Klinik Mitra Medistra ini, admin berperan mengelola data user baik itu admin, dokter, maupun perawat. Untuk menambahka data user, admin tinggal menuju halaman jenis user yang ingin ditambah, baik admin, dokter, atau perawat, kemudian mengisikan tiga data yaitu nama admin, dokter, atau 
perawat yang baru, username, dan password kemudian sistem akan menyimpannya di database. Untuk mengubah data user, di halaman data jenis user yang ingin diubah baik admin, dokter, atau perawat, admin tinggal mengubah data yang diinginkan kemudian sistem akan menyimpannya ke database. Untuk menghapus data user, di halaman data jenis user yang ingin dihapus baik admin, dokter, atau perawat, admin tinggal memilih data yang ingin dihapus kemudian sistem akan menghapusnya dari database.

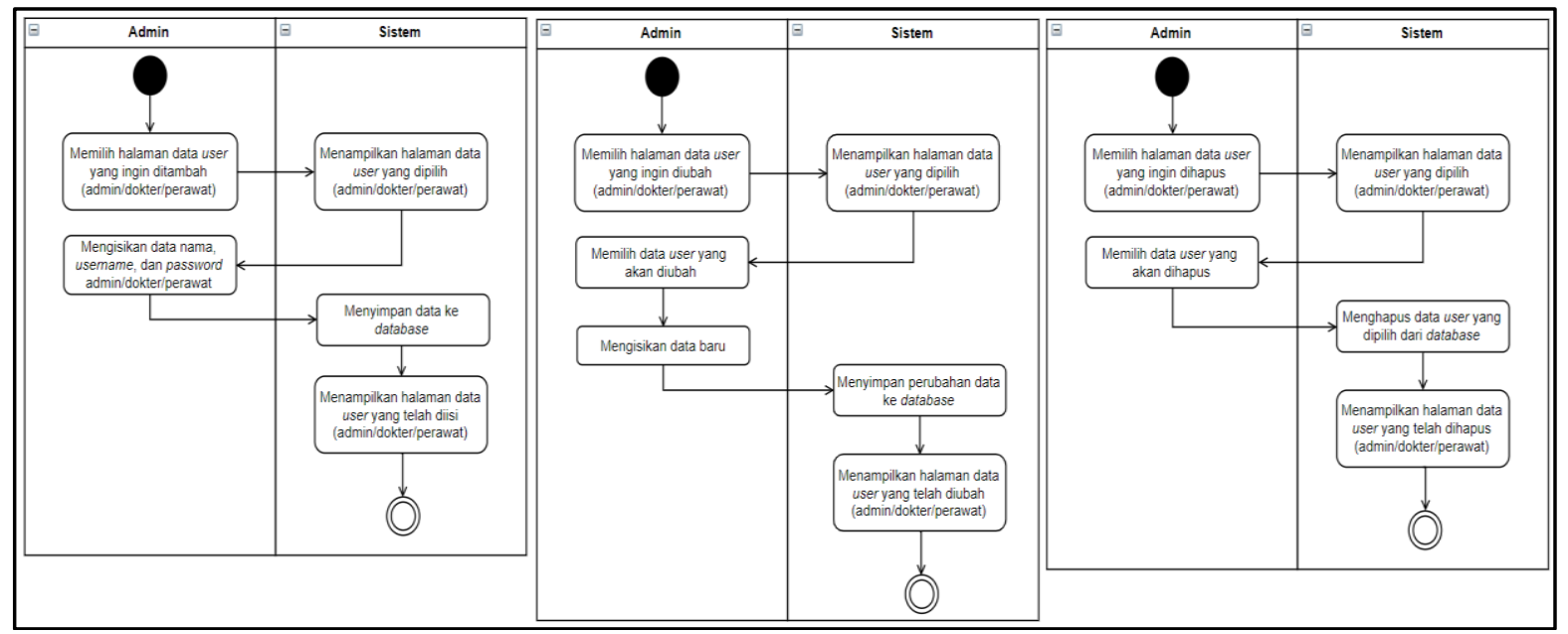

Gambar 9.Proses Mengelola User

c. Proses menambahkan pasien ke antrian

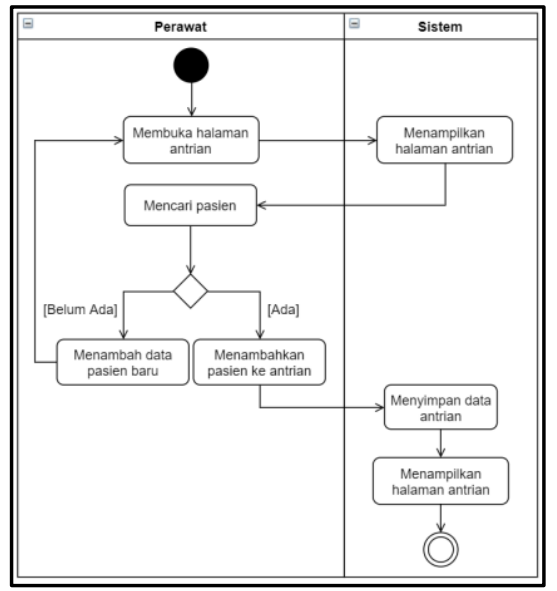

Gambar 10. Proses Menambahkan Antrian

User yang dapat menambahkan pasien ke antrian adalah perawat. Pada halaman antrian, perawat dapat mencari data pasien kemudian menambahkannya ke antrian dengan mengisikan data-data yang diperlukan. Namun jika data pasien belum ada, artinya pasien tersebut adalah pasien baru, maka data pasien itu perlu ditambahkan dulu kemudian baru dimasukkan ke antrian.

\section{d. Proses mengelola data pasien}

User yang dapat menambahkan data pasien baru adalah perawat. Pada halaman data pasien, perawat perlu mengisikan data-data identitas pasien selengkap mungkin, kemudian sistem dapat menyimpannya ke database. User yang dapat mengubah data pasien adalah dokter dan perawat. Pada halaman data pasien, dokter atau perawat perlu mencari pasien yang datanya ingin diubah, kemudian di halaman data pasien tersebut perawat mengisikan data-data baru untuk mengganti data lama, kemudian sistem dapat menyimpannya ke database. User yang dapat menghapus data pasien adalah perawat. Pada halaman data .pasien, perawat perlu mencari pasien yang datanya ingin diubah, mengklik pasien tersebut sehingga ditampilkan data lengkapnya, baru kemudian menghapus data pasien tersebut 


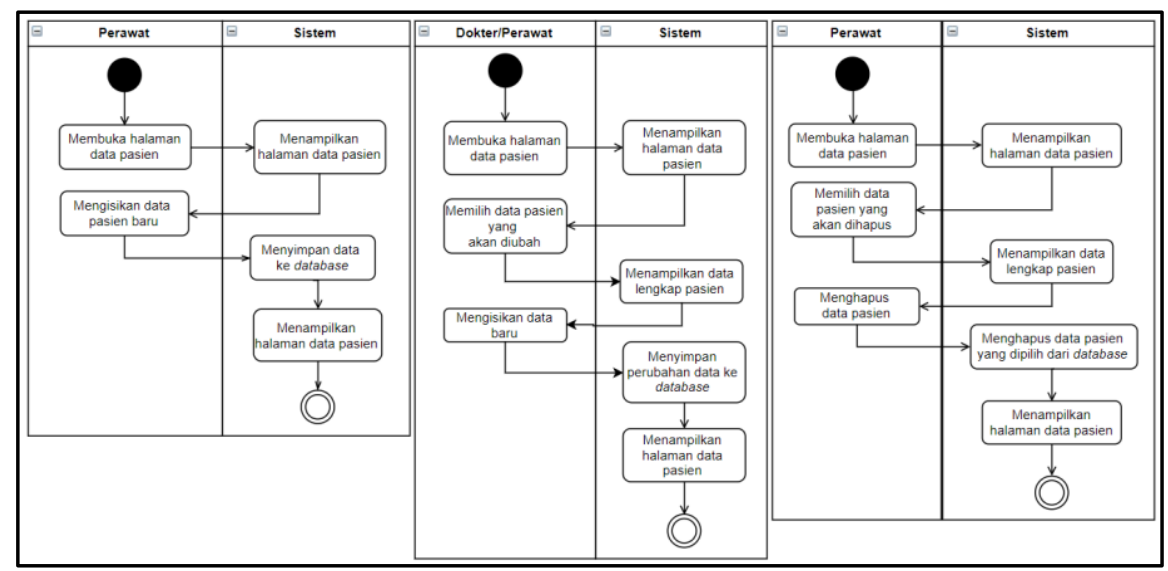

Gambar 11. Proses Mengelola Data Pasien

e. Proses mengelola data rekam medis

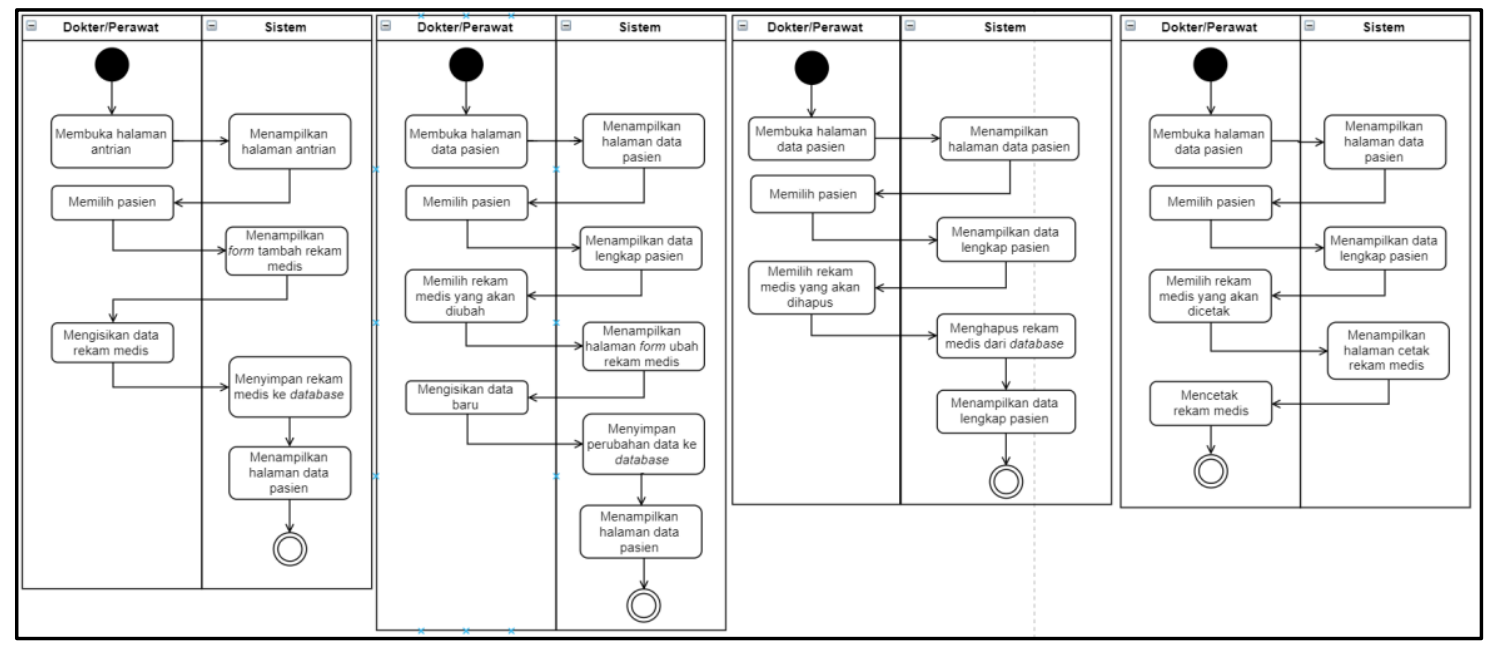

Gambar 12. Proses Mengelola Data Rekam Medis

Dari halaman antrian, dokter dan perawat dapat memilih pasien, kemudian mengisikan data rekam medis pada form rekam medis yang ditampilkan, lalu sistem akan menyimpannya ke database. Dokter dan perawat juga dapat memilih pasien kemudian pada halaman data lengkap pasien tersebut memilih rekam medis yang akan diubah. Kemudian pada form ubah rekam medis, tinggal mengisikan data baru kemudian sistem akan menyimpan perubahan ke database. Selain itu, dokter dan perawat dapat memilih pasien kemudian pada halaman data lengkap pasien tersebut memilih rekam medis yang akan dihapus. Setelah mengklik tombol hapus, sistem akan menghapus data rekam medis tersebut dari database.Yang terakhir, dokter dan perawat pada halaman data lengkap pasien dokter dan perawat dapat memilih rekam medis yang akan dicetak. Setelah mengklik tombol cetak, sistem akan menampilkan data rekam medis tersebut dalam format yang sesuai untuk dicetak.

\subsubsection{Use case diagram}

Pada Sistem Pencatatan Rekam Medis Klinik Mitra Medistra terdapat tiga jenis user, yaitu admin, dokter, dan perawat. Admin dapat menambah, mengubah, dan menghapus data dokter, perawat, serta data admin lain. Dokter dapat melakukan beberapa fungsi yaitu mencari dan mengubah detail data pasien yang sudah ada, serta menambah, mengubah, menghapus, dan mencetak data rekam medis. Perawat dapat melakukan beberapa fungsi yaitu mencari, menambah, mengubah, maupun menghapus data pasien, menambahkan pasien ke antrian, serta menambah, mengubah, menghapus, dan mencetak data rekam medis. 


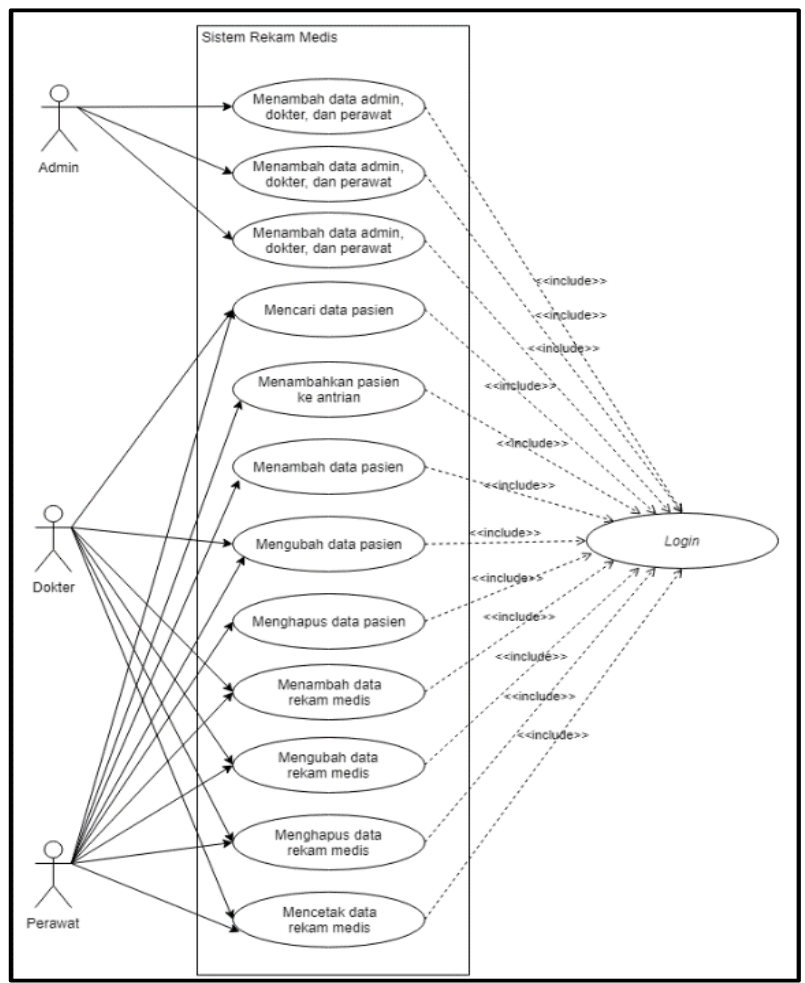

Gambar 13. Use Case Diagram

\section{HaSil dan PeMbahasan}

\subsection{Implementasi Sistem}

\subsubsection{Halaman utama sistem pencatatan rekam medis}

Pada halaman utama website Sistem Pencatatan Rekam Medis Klinik Mitra Medistra terdapat formulir pengisian username dan password yang digunakan untuk login ke dalam sistem. Tampilan halaman utama dapat dilihat pada Gambar 14.

\subsubsection{Halaman antrian}

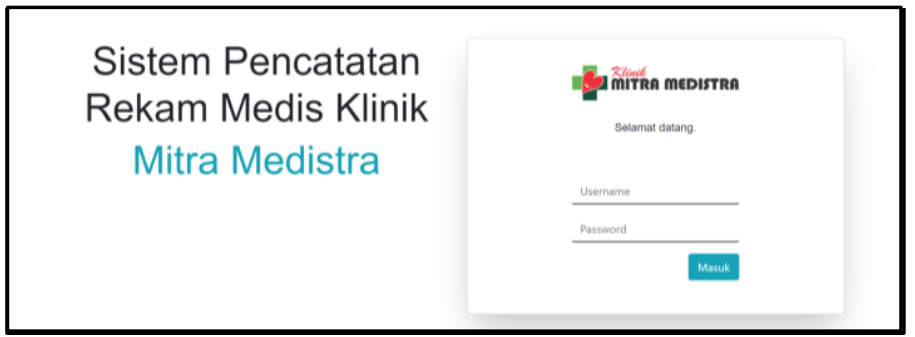

Gambar 14. Halaman Utama

Ketika pasien datang ke klinik, maka pegawai yang bertugas, biasanya perawat perlu menuliskan keterangan pasien tersebut sebelum pasien bertemu dokter. Pasien yang baru datang ini akan dimasukkan ke antrian. Gambar 15 menampilkan halaman pengisian data antrian.

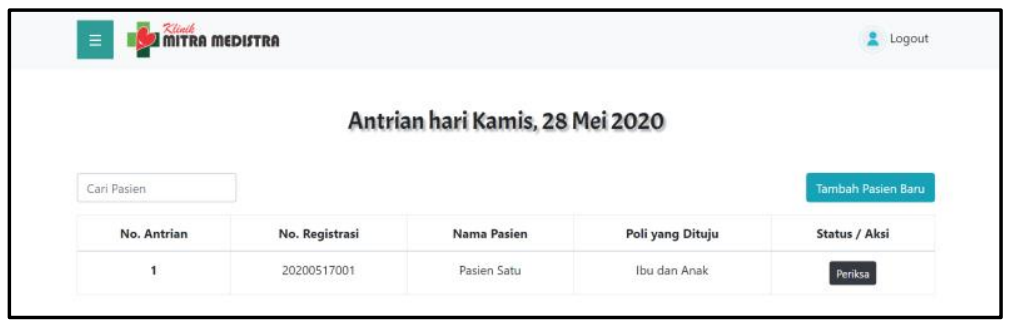

Gambar 15. Halaman Antrian 


\subsubsection{Halaman data pasien}

Gambar 16 adalah implementasi halaman data pasien di mana seluruh data pasien akan ditampilkan.

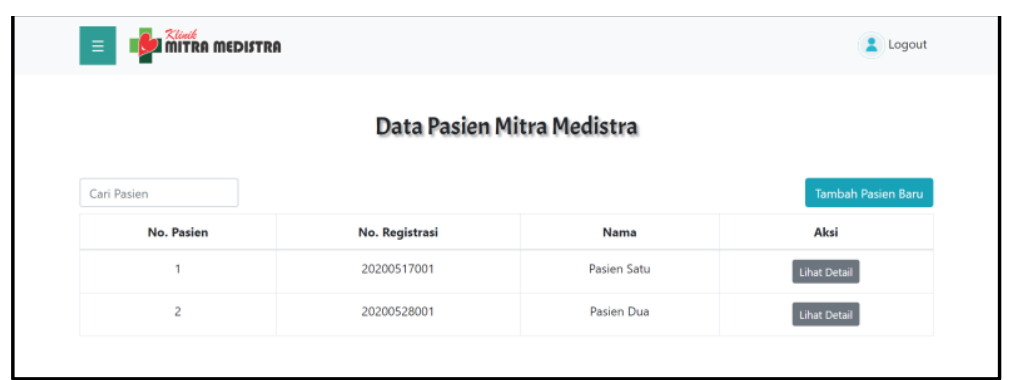

Gambar 16. Halaman Data Pasien

\subsubsection{Halaman data masing-masing pasien}

Gambar 17 menunjukkan implementasi halaman data individu pasien meliputi identitas dan rekam medisnya.

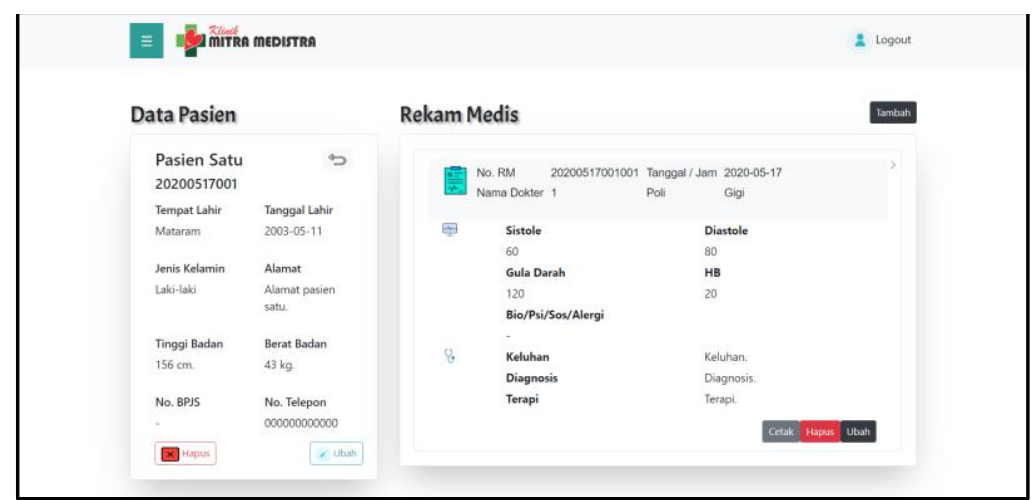

Gambar 17. Halaman Data Masing-Masing Pasien

\subsubsection{Halaman formulir rekam medis}

Gambar 18 menampilkan formulir yang digunakan dalam penambahan maupun pengubahan data rekam medis.

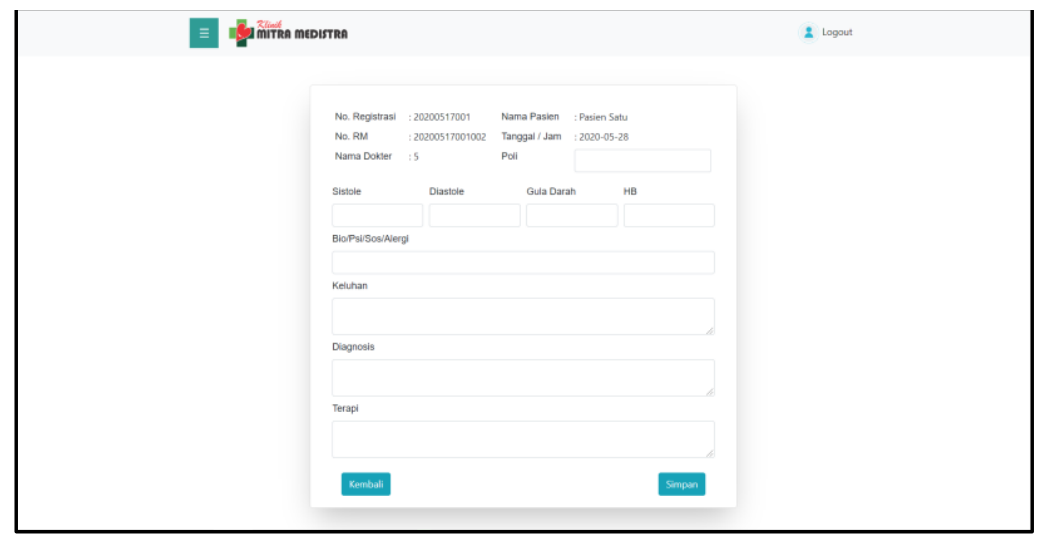

Gambar 18. Halaman Formulir Rekam Medis

\subsubsection{Halaman cetak rekam medis}

Data rekam medis yang sudah ada dapat dicetak. Tampilan halaman rekam medis sebelum dicetak diperlihatkan di Gambar 19. 


\subsubsection{Halaman data dokter}

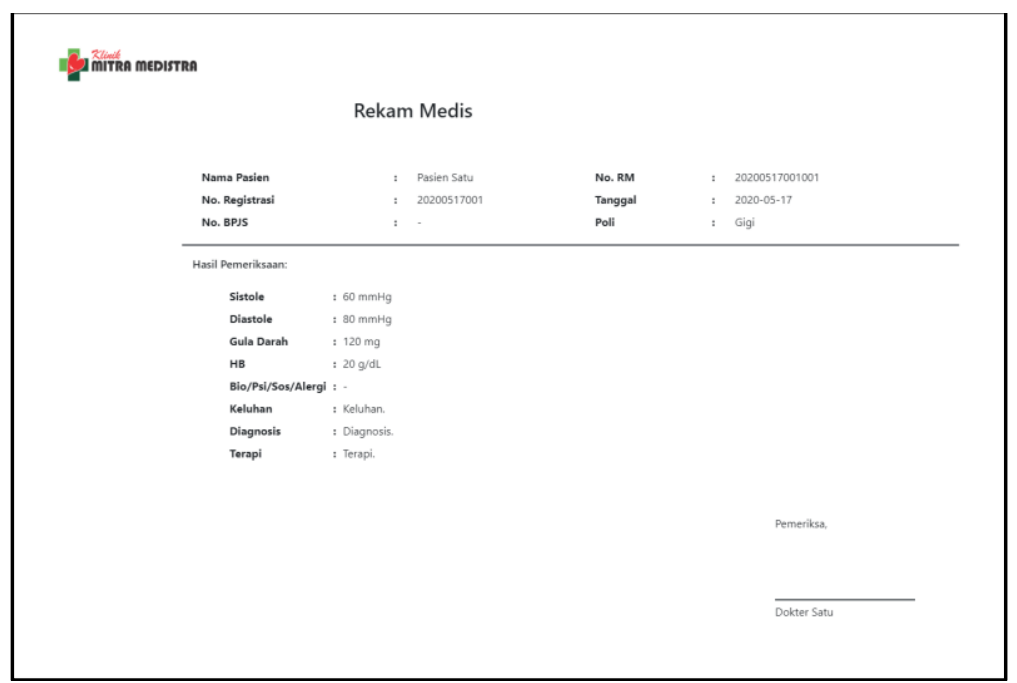

Gambar 19. Halaman Cetak Rekam Medis

Admin mengatur data dokter yang dapat mengakses sistem. Berikut adalah implementasi halaman data-data dokter yang dikelola oleh admin.

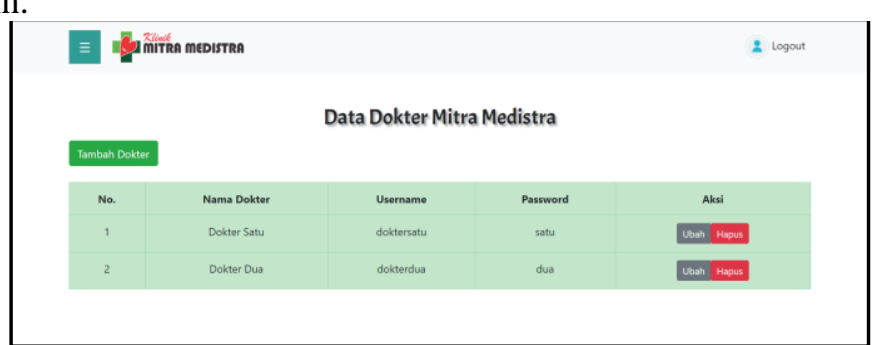

Gambar 20. Halaman Data Dokter

\subsubsection{Halaman data perawat}

Admin mengatur data perawat yang dapat mengakses sistem. Berikut adalah implementasi halaman data-data perawat yang dikelola oleh admin.

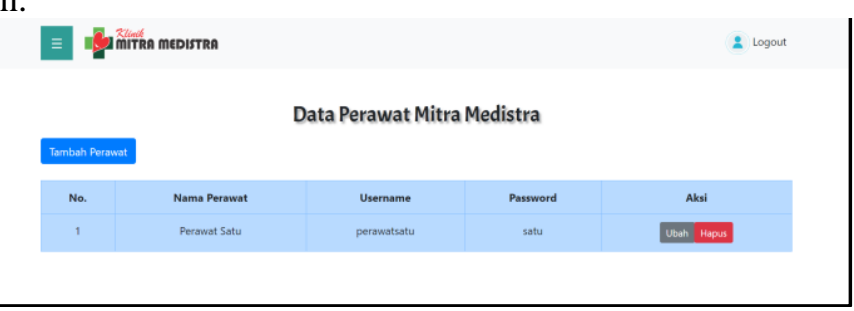

Gambar 21. Halaman Data Perawat

\subsubsection{Halaman data admin}

Admin mengatur data admin yang dapat mengakses sistem. Berikut adalah implementasi halaman data-data admin yang juga dikelola oleh admin.

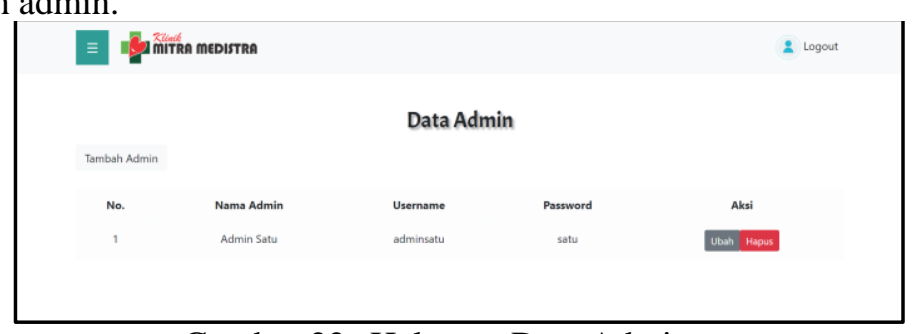

Gambar 22. Halaman Data Admin 


\subsection{Hasil Pengujian Black Box}

Pengujian black box dilakukan untuk menguji apakah fungsionalitas sistem sudah berjalan seperti yang diinginkan. Hasil pengujian black box pada fungsi-fungsi di Sistem Pencatatan Rekam Medis Klinik Mitra Medistra dijelaskan pada Tabel 2 .

TABEL 1. Hasil Uji Black Box

\begin{tabular}{|c|c|c|c|c|c|}
\hline $\begin{array}{c}\text { Fitur yang } \\
\text { diuji }\end{array}$ & Input & $\begin{array}{c}\text { Hasil yang } \\
\text { diharapkan }\end{array}$ & \multicolumn{2}{|c|}{ Hasil Pengujian } & Kesimpulan \\
\hline Login & $\begin{array}{l}\text { Username } \\
\text { dan } \\
\text { password } \\
\text { yang salah }\end{array}$ & $\begin{array}{l}\text { Sistem kembali ke } \\
\text { halaman utama } \\
\text { dan menampilkan } \\
\text { alert "username } \\
\text { atau password } \\
\text { salah." }\end{array}$ & & & Valid \\
\hline Login & $\begin{array}{l}\text { Username } \\
\text { dan } \\
\text { password } \\
\text { admin }\end{array}$ & $\begin{array}{l}\text { Sistem } \\
\text { menampilkan } \\
\text { halaman } \\
\text { dashboard admin } \\
\text { yaitu pada } \\
\text { halaman data } \\
\text { dokter. }\end{array}$ & 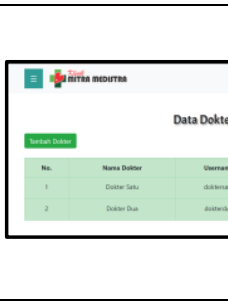 & 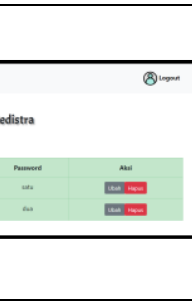 & Valid \\
\hline Login & $\begin{array}{l}\text { Username } \\
\text { dan } \\
\text { password } \\
\text { data dokter } \\
\text { atau perawat } \\
\end{array}$ & $\begin{array}{l}\text { Sistem } \\
\text { menampilkan } \\
\text { halaman antrian. }\end{array}$ & 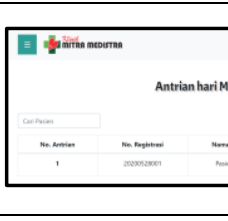 & $\begin{array}{ll} & \\
m & \end{array}$ & Valid \\
\hline $\begin{array}{l}\text { Mencari pasien } \\
\text { di halaman } \\
\text { antrian }\end{array}$ & $\begin{array}{l}\text { Nama atau } \\
\text { nomor } \\
\text { registrasi } \\
\text { pasien baru }\end{array}$ & $\begin{array}{l}\text { Sistem } \\
\text { memberitahu } \\
\text { bahwa data tidak } \\
\text { ditemukan. }\end{array}$ & \begin{tabular}{|ll}
002 & $\times$ \\
Dotat pasien tidak ditemulan.
\end{tabular} & & Valid \\
\hline $\begin{array}{l}\text { Mencari pasien } \\
\text { di halaman } \\
\text { antrian }\end{array}$ & $\begin{array}{l}\text { Nama atau } \\
\text { nomor } \\
\text { registrasi } \\
\text { pasien lama }\end{array}$ & $\begin{array}{l}\text { Sistem } \\
\text { menampilkan data } \\
\text { pasien yang dicari. }\end{array}$ & $\begin{array}{|ll|}\text { dues } & x \\
20200528001 & \text { Pasien Dua } \\
\end{array}$ & Mmake ke antian & Valid \\
\hline $\begin{array}{l}\text { Mencari pasien } \\
\text { di halaman } \\
\text { data pasien }\end{array}$ & $\begin{array}{l}\text { Nama atau } \\
\text { nomor } \\
\text { registrasi } \\
\text { pasien baru }\end{array}$ & $\begin{array}{l}\text { Sistem } \\
\text { memberitahu } \\
\text { bahwa data tidak } \\
\text { ditemukan. }\end{array}$ & $\infty \quad$ noromite & 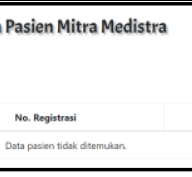 & Valid \\
\hline $\begin{array}{l}\text { Mencari pasien } \\
\text { di halaman } \\
\text { data pasien }\end{array}$ & $\begin{array}{l}\text { Nama atau } \\
\text { nomor } \\
\text { registrasi } \\
\text { pasien lama }\end{array}$ & $\begin{array}{l}\text { Sistem } \\
\text { menampilkan data } \\
\text { pasien yang dicari. }\end{array}$ & $=$ & $=$ & Valid \\
\hline $\begin{array}{l}\text { Memasukkan } \\
\text { data pasien ke } \\
\text { antrian }\end{array}$ & $\begin{array}{l}\text { Data pasien } \\
\text { lama dan } \\
\text { data } \\
\text { kunjungan } \\
\text { pasien }\end{array}$ & $\begin{array}{l}\text { Data pasien } \\
\text { masuk ke tabel } \\
\text { antrian dan } \\
\text { ditampilkan oleh } \\
\text { sistem. } \\
\end{array}$ & 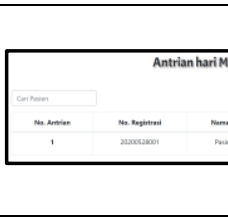 & 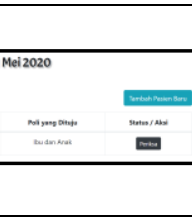 & Valid \\
\hline $\begin{array}{l}\text { Menambahkan } \\
\text { data pasien } \\
\text { baru }\end{array}$ & $\begin{array}{l}\text { Data pasien } \\
\text { baru }\end{array}$ & $\begin{array}{l}\text { Data pasien } \\
\text { tersimpan dan } \\
\text { ditampilkan di } \\
\text { halaman data } \\
\text { pasien. }\end{array}$ & 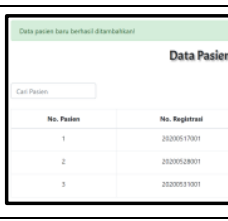 & $=$ & Valid \\
\hline
\end{tabular}




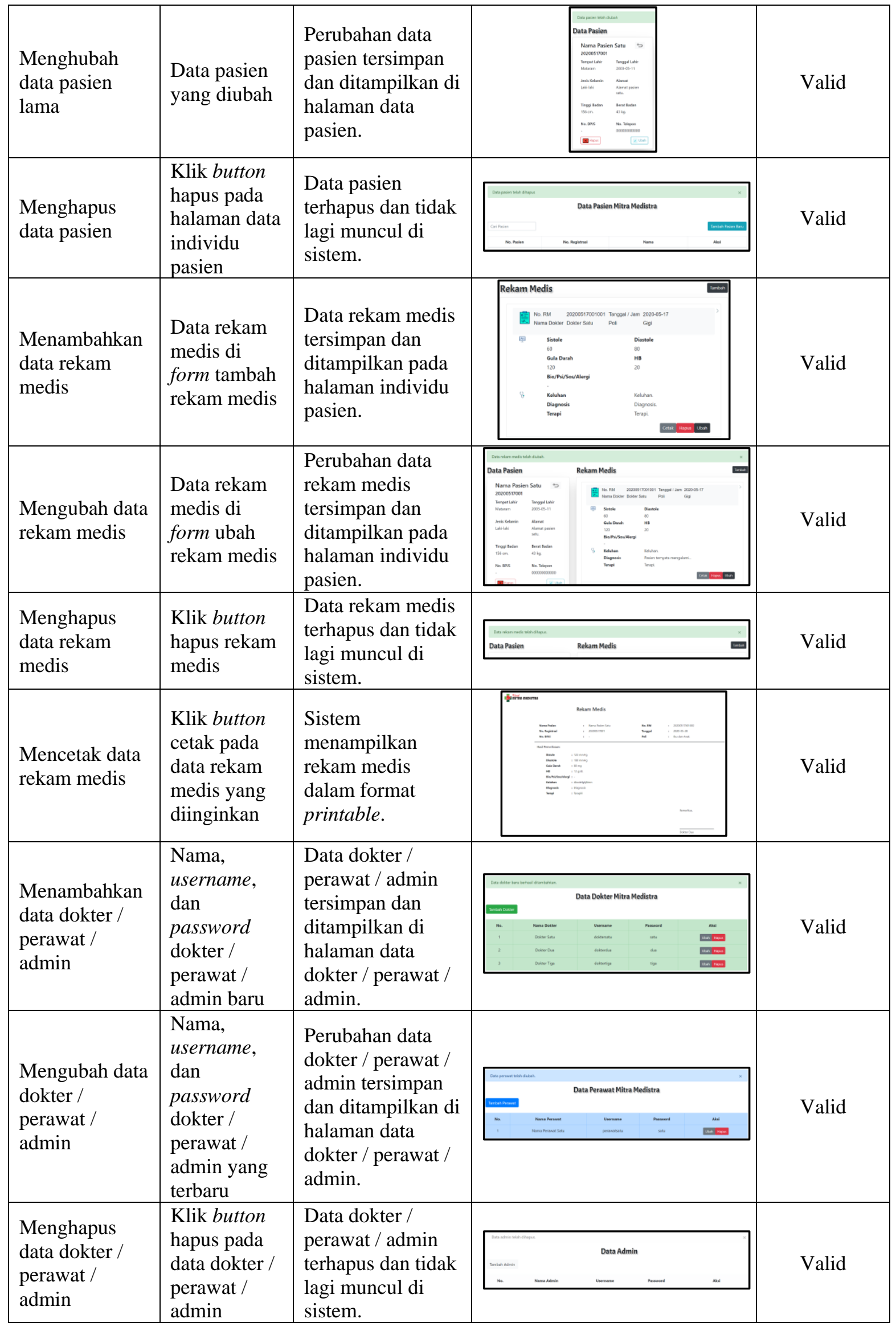




\section{KESIMPULAN DAN SARAN}

\subsection{Kesimpulan}

Berdasarkan pengabdian dan pembuatan sistem yang telah dilakukan, didapatkan beberapa kesimpulan sebagai berikut.

a. Pembuatan Sistem Pencatatan Rekam Medis Klinik Mitra Medistra ini berfokus pada permasalahan pencatatan dan rekap rekam medis di Klinik Mitra Medistra. Pada sistem ini dokter dapat menyimpan rekam medis pasien, dan perawat dapat mengelola data pasien serta membantu dokter melakukan rekap rekam medis jika diperlukan. Sedangkan admin berperan sebagai pengatur data-data user yang dapat mengelola sistem.

b. Hasil pengujian dengan metode Black Box seluruh fungsi telah berjalan seperti yang diharapkan sesuai dengan yang diharapkan oleh pengguna sistem, khususnya tenaga pekerja kesehatan di Klinik Mitra Medistra.

\subsection{Saran}

Karena masih banyaknya kekurangan dari penulis dalam mengembangkan sistem ini, terdapat beberapa saran untuk dapat membuat sistem ini menjadi lebih baik pada waktu yang akan datang, di antaranya:

a. Penanganan form dalam sistem masih kurang baik dalam hal pemberian keterangan/alert. Diharapkan kedepannya sistem dikembangkan sehingga dalam pengisian data pasien dan rekam medis langsung diberikan pesan error yang jelas di dalam form.

b. Diharapkan kedepannya sistem mencatat lebih banyak data yang relevan dengan sistem di klinik, seperti data lengkap dokter dan pasien, serta statistik pasien maupun klasifikasi pasien berdasarkan berbagai kriteria, sehingga memudahkan dalam evaluasi perkembangan klinik di masa mendatang.

\section{DAFTAR PUSTAKa}

[1] E. Y. Anggraeni dan R. Irviani, Pengantar Sistem Informasi. Yogyakarta: Andi, 2017, pp. 2-32.

[2] R. Yanto, Manajemen Basis Data Menggunakan MySQL. Yogyakarta: Deepublish, 2016, pp. 10-41.

[3] Haviluddin, "Memahami Penggunaan UML (Unified Modelling Language)," Jurnal Informatika Mulawarman, vol. 6, no. 1, hal. Page 1-15, 2011.

[4] R. Parahita, I. B. K. Widiartha, A. Zubaidi, "Sistem Informasi Perhotelan Berbasis Web Service, Studi Kasus di Pulau Lombok," Journal of Computer Science and Informatics Engineering (J-Cosine), vol. 1, no. 1, hal. 46, 2018.

[5] L. J. M. Siagian, Otomatisasi Pengujian Perangkat Lunak (Software Test Automation). Yogyakarta: Deepublish, 2018, pp. 6. 